\title{
Study on the Liability-Sharing of Carbon Emissions in Cities of Hebei Province Based on DEA Model
}

\author{
Jingmin Wang \\ Department of Economic Management \\ North China Electric Power University \\ Baoding, China \\ jingminwang126@126.com
}

\author{
Lei Feng \\ Department of Economic Management \\ North China Electric Power University \\ Baoding, China \\ fenglei0011@126.com
}

\begin{abstract}
Based on the decomposition of the overall national carbon reduction targets to municipalities, Hebei Province, sharing responsibility for carbon emissions. In this paper, prefectural-level city in Hebei Province as an example, use of undesirable outputs that carbon emissions as model inputs, the population, energy consumption and GDP as a model output variable. In accordance with the characteristics of the development of economy and society in Hebei Province forecasts the input and output data, using input-oriented DEA model to evaluate the efficiency and economic of the responsibility for carbon emission of 11 cities in Hebei Province in 2015 , and based on the evaluation results gives suggestions to the cities for improvement. Proved that during the reduction process it has possibility to achieve economic development, it provides a reference to prefectural-level city in Hebei province for developing low-carbon economy.
\end{abstract}

Keywords-data evelopment analysis; carbon emissions; hebei Province; prefecture-level cities

\section{INTRODUCTION}

As global temperatures rise,reduce greenhouse gas emissions has become a global consensus. The international community has undertaken a number of positive measures. From December 1997 in Kyoto, Japan, passed the world's first prescribed a quantitative greenhouse gas reduction obligations under the "Kyoto Protocol", to the December 2007 adopted the "Bali roadmap" ,proposed different requirements for developed and developing countries mitigate carbon emissions; On the meeting which was held in Copenhagen December 2009 ,Chine gave a commitment that in 2020 our carbon intensity decreased by 40 to $45 \%$ compared to 2005 . By the end of 2011, in the climate conference in Durban ,the representative of China said that , the Chinese government decided to greatly reduced the carbon intensity within five years, by 2015 the country carbon emissions intensity decreased by $17 \%$ compared to 2010 , China is facing an increasingly powerful pressure to reduce emissions. In order to achieve these goals, we must break down the carbon emission reduction targets to various provinces, cities and even smaller economic unit of society, formulate regional low-carbon development goals and metrics, to clarify its carbon reduction responsibilities.

Regard to the apportion of carbon emissions responsibility, domestic and foreign scholars have conducted a wide range of related research. Lin Tan, Ning Junfe ${ }^{[1]}$ studied the allocation efficiency of the European Union carbon emission rights , using zero and DEA model, at the national level. Zheng Liqun ${ }^{[2]}$ apportioned responsibility for carbon emissions of China's provinces and autonomous regions, break down the country's overall carbon reduction targets to the provinces. Wang Zhen and Zhao Dingtao ${ }^{[3]}$, based on the perspective of producers and consumers environmental liability,established a regional carbon emissions burden sharing model. Xu Yingzhi and Zhang $\mathrm{Yun}^{[4]}$,for the "carbon leakage" problems arising between regional trade, using multi-regional trade input-output model in the framework of inter-regional, analyzed carbon emissions responsibility of each region and the differences of carbon emissions responsibility in different industries. Taking these studies can find that energy consumption is a major source of carbon emissions, but research on energy carbon emissions almost concentrated at the national scale, relatively few studies on the provincial and municipal scale, and specific value of energy carbon emissions also failed to clear ,therefore, carbon emissions needs further detailed study on the municipal level.

Taking these studies can find that energy consumption is a major source of carbon emissions, but research on energy carbon emissions almost concentrated at the national scale, relatively few studies on the provincial and municipal scale, and specific value of energy carbon emissions also failed to clear ,therefore, carbon emissions needs further detailed study on the municipal level.

\section{TheOreticAl BASIS AND TheOreticAl Models}

Data envelopment analysis is a non-parametric programming units relative effectiveness evaluation method proposed by A.Charnes Operations Research famous American family and WWCooper other scholars based on "relative efficiency" concept and multi-input and multi-output index, to exclude a lot of subjective factors, with strong objectivity[5].The core idea of DEA model is to use inputoutput data output projected maximum or minimum investment boundaries. It not only can assess and sort the relative effectiveness of each sort of decision making units of the same type, but also can analysis each of non-DEA effective decision-making unit causes and improve the direction, provide important information for the management decision makers [6].

Assuming a evaluation system with $\mathrm{N}$ of decision making units of the same type (DMU), each decision unit has m kinds of inputs and $\mathrm{s}$ kinds of outputs, establish the relative 
efficiency of the decision-making unit evaluation BCC model is as follows:

$$
\left\{\begin{array}{l}
\min \left[\theta-\varepsilon\left(e_{1}^{T} s^{-}+e_{2}^{T} s^{+}\right)\right]=\theta^{*} \\
\sum_{j=1}^{n} \lambda_{j} X_{i j}+s_{i}^{-}=\theta X_{0} \\
\sum_{j=1}^{n} \lambda_{j} X_{i j}-s_{i}^{+}=Y_{0} \\
\sum_{j=1}^{n} \lambda_{j}=1, \lambda_{j} \geq 0, j=1, \ldots, n \\
\theta(\text { Unconstrained }), s^{+} \geq 0, s^{-} \geq 0
\end{array}\right.
$$

Formula(1): $\theta$ is the relative efficiency; is the nonarchimedean infinitesimal; $\mathrm{e}_{1}$ is $\mathrm{m}$-dimensional unit vector; $s^{-}=\left[s_{1}^{-}, s_{2}^{-}, \ldots, s_{s}^{-}\right]$is the difference vector of input; $\mathrm{e}_{2}$ is the $\mathrm{s}^{-}$ dimensional unit column vector ; $s^{+}=\left[s_{1}^{+}, s_{2}^{+}, \ldots, s_{s}^{+}\right]$is the difference vector of output; $\theta^{*}$ is the relative efficiency target;n is the number of DMU need to evaluate; $\lambda \mathrm{j}(\mathrm{j} 1,2, \ldots, \mathrm{n})$ is the weight of right combination of DMU; $X_{i j}$ is the $i$-th input of the $j$-th DMU; $X_{j}$ is the input of the $j$-th DUM; $X_{j}=\left[X_{1 j}, X_{2 j}, \ldots, X_{i j}, \ldots, X_{m j}\right] ; i=1,2, \ldots, m ; X_{0}$ is the inputs of the DMU intend to assess; $Y_{i j}$ is the $i$-th output of the $j$-th DMU; $Y_{j}$ is the output of the $j$-th DUM; $\lambda_{0}, S^{0-}, S^{0^{+}}, \theta^{0}$ are the optimal solution of the $\mathrm{C}^{2} \mathrm{R}$ model.

\section{INDICATOR SELECTION AND PROCESSING OF DATA SOURCES}

This article refers to the method proposed by Lins and Gomes[7],the population, GDP and energy consumption as the amount of output variables, the carbon emissions as the only input variables in the model. GDP is the desired output, Carbon dioxide emissions as undesirable output, currently, when dealing with undesirable output, the main method of DEA model is input method.Countdown conversion method, hyperbolic method, convert vector method, Directional distance function method, SBM model method ,etc[8][9]. Since other methods may have the problem of no effective solutions, therefore, this article make undesirable outputs as inputs to deal with carbon emissions. Various data sources and processes as follows:

\section{A. Calculate the Actual Carbon Emissions of Every City.}

Using the Kaya formula proposed by a Japanese scholar Mao Yang Professor(Kaya Yoichi).

$$
C=P \times(G D P / P) \times(E / G D P) \times(C / E)
$$

Note:C-Carbon emissions; P-Population;E-Energy Consumption; GDP/P-GDP of per capita; E/GDP-Energy intensity, that is energy consumption per unit of GDP;C/ECarbon emission factor.0.6799tCO2/tce.

B. Based on the GDP data of each city from 2008 to 2012 from "Hebei Province Statistical Yearbook,"using the average growth rate method to forecast the GDP data of each city in2015. As show in the TABLE I below.

C. Based on the population data of each city from 2008 to 2012 from "Hebei Province Statistical Yearbook,"using the average growth rate method to forecast the population data of each city in 2015.As show in the TABLE I below.

D. Using heat consumption law The input data of Energy consumption directly use heat consumption law to translated a variety of energy into a unified total.The data from"Hebei Province Statistical Yearbook" in the calendar year.According to Energy/GDP elasticity, can calculate the total energy consumption in each city in2015. As show in TABLE I below.

E. According to the formula (2) can predicted the actual carbon emissions of each city in Hebei Province in 2015as

\begin{tabular}{|c|c|c|c|c|c|}
\hline City & $\begin{array}{l}\text { Populati } \\
\text { on ( Ten } \\
\text { thousan } \\
\text { d ) }\end{array}$ & $\begin{array}{l}\text { Energy } \\
\text { Consumption } \\
\text { Per Unit Of } \\
\text { GDP (tce/Ten } \\
\text { thousand } \\
\text { yuan) }\end{array}$ & $\begin{array}{l}\text { GDP } \\
\text { (One } \\
\text { hundre } \\
\text { d } \\
\text { million } \\
\text { yuan) }\end{array}$ & $\begin{array}{l}\text { Total } \\
\text { Energy } \\
\text { Consumpti } \\
\text { on } \\
\text { (Ten } \\
\text { thousand } \\
\text { tons } \\
\text { standard } \\
\text { coal) }\end{array}$ & $\begin{array}{l}\text { Carbon } \\
\text { Emissio } \\
\text { ns } \\
\text { (Ten } \\
\text { thousan } \\
\text { d tons) }\end{array}$ \\
\hline SJZ & 1075.1 & 0.879 & 7423.0 & 6524.87 & 4760.8 \\
\hline $\mathrm{CD}$ & 357.0 & 0.810 & 2395.9 & 1940.70 & 1446.5 \\
\hline ZJK & 450.7 & 0.954 & 2139.8 & 2041.39 & 1516.9 \\
\hline QHD & 309.3 & 0.664 & 1904.2 & 1264.40 & 883.82 \\
\hline $\mathrm{TS}$ & 788.2 & 1.289 & 10635 & 13709.5 & 9982.9 \\
\hline LF & 464.8 & 2.138 & 3091.0 & 6608.64 & 4839.4 \\
\hline $\mathrm{BD}$ & 1164.8 & 1.133 & 4341.4 & 4918.91 & 3438.3 \\
\hline $\mathrm{CZ}$ & 744.6 & 2.003 & 4705.2 & 9424.70 & 6937.8 \\
\hline HS & 446.2 & 1.850 & 1395.3 & 2581.45 & 1804.4 \\
\hline XT & 740.1 & 1.237 & 2369.4 & 2930.95 & 2048.7 \\
\hline HD & 964.68 & 1.064 & 5213.5 & 5547.26 & 4077.5 \\
\hline
\end{tabular}
show in the TABLE I below.

F. The input-output data of DEA model are shown in TABLE II.

TABLE I. EACH FORECAST DATA OF EACH CITY IN HEBEI PROVINCE IN 2015

Note:SJZ is in the name of Shijiazhuang,CD is in the name of Chengde,ZJK is in the name of Zhangiiakou,QHD is in the name of Qinhuangdao,TS is in the name of Tangshan,LF is in the name of Langfang, $\mathrm{BD}$ is in the name of Baoding, $\mathrm{CZ}$ is in the name of Cangzhou,HS is in the name of Hengshui,XT is in the name of Xingtai,HD is in the name of Handan. 
TABLE II. INPUT-OUTPUT CONDITIONS

\begin{tabular}{|c|c|c|c|c|}
\hline \multirow{2}{*}{ City } & $\begin{array}{c}\text { Input } \\
\text { Indicators }\end{array}$ & \multicolumn{3}{|c|}{ Output Indicators } \\
\cline { 2 - 5 } & $\begin{array}{c}\text { Carbon } \\
\text { emissions } \\
\text { (Ten } \\
\text { thousand } \\
\text { tons) }\end{array}$ & $\begin{array}{c}\text { Population } \\
\text { (Ten } \\
\text { thousand) }\end{array}$ & $\begin{array}{c}\text { GDP } \\
\text { (One } \\
\text { hundred } \\
\text { million yuan) }\end{array}$ & $\begin{array}{c}\text { Energy } \\
\text { Consumption } \\
\text { (Ten thousand } \\
\text { tons standard } \\
\text { coal) }\end{array}$ \\
\hline SJZ & 4760.88 & 1075.19 & 7423.06 & 6121.09 \\
\hline CD & 1446.55 & 357.08 & 2395.93 & 1500.83 \\
\hline ZJK & 1516.93 & 450.78 & 2139.82 & 1835.56 \\
\hline QHD & 883.82 & 309.33 & 1904.22 & 1119.78 \\
\hline TS & 9982.99 & 788.25 & 10635.82 & 12395.06 \\
\hline LF & 4839.44 & 464.88 & 3091.04 & 6132.19 \\
\hline BD & 3438.32 & 1164.89 & 4341.49 & 5251.01 \\
\hline CZ & 6937.86 & 744.64 & 4705.29 & 9638.91 \\
\hline HS & 1804.44 & 446.25 & 1395.38 & 3092.30 \\
\hline XT & 2048.73 & 740.19 & 2369.40 & 2963.86 \\
\hline HD & 4077.53 & 964.68 & 5213.59 & 4913.74 \\
\hline
\end{tabular}

According to the data of TABLE II, using C2R model, using Matlab software to solve, which take $=10-10$, get the evaluation results of carbon emissions of each city in Hebei Province by 2015.As TABLE III follows.

As the definition shows: The $\theta^{*}$ of the cities as Qinhuangdao(DMU4),Baoding(DMU7),Hengshui(DMU9),Xi ngtai(DMU10) are one, and the slack variables as $\mathrm{s}_{-}=0$, $\mathrm{s}^{*+}=0$, So they are all effective DEA . Shijiazhuang(DMU1), Chengde(DMU2),Zhangjiakou (DMU3), Tangshan(DMU5), Langfang(DMU6),Cangzhou(DMU8), Handan(DMU11), are valid DEA,the improvement suggestions are shown in TABLE IV as follows:

TABLE III. THE EVALUATION RESULTS OF CARBON EMISSIONS OF EACH CITYIN HEBEI PROVINCE BY 2015

\begin{tabular}{|l|c|c|c|c|c|}
\hline \multicolumn{1}{|c|}{ DMU } & $\theta^{*}$ & $\sum_{j=1}^{n} \lambda_{j}$ & $\begin{array}{l}\text { Technical } \\
\text { efficiency }\end{array}$ & $\begin{array}{l}\text { Economies } \\
\text { of scale }\end{array}$ & $\begin{array}{l}\text { Effectiv } \\
\text { eness }\end{array}$ \\
\hline DMU1(SJZ) & 0.911 & 4.104 & valid & decreasing & valid \\
\hline DMU2(CD) & 0.801 & 1.269 & valid & decreasing & valid \\
\hline DMU3(ZJK) & 0.859 & 0.882 & valid & ascending & valid \\
\hline DMU4(QHD) & 1.000 & 1.000 & effective & constant & effective \\
\hline DMU5(TS) & 0.807 & 6.307 & valid & decreasing & valid \\
\hline DMU6(LF) & 0.750 & 2.130 & valid & decreasing & valid \\
\hline DMU7(BD) & 1.000 & 1.000 & effective & constant & effective \\
\hline DMU8(CZ) & 0.819 & 3.279 & valid & valid & valid \\
\hline DMU9(HS) & 1.000 & 1.000 & effective & constant & effective \\
\hline DMU10(XT) & 1.000 & 1.000 & effective & constant & effective \\
\hline DMU11(HH) & 0.824 & 2.955 & valid & decreasing & valid \\
\hline
\end{tabular}

TABLE IV. ECONOMIC EVALUTION OF CARBON EMISSIONS OF EACH CITY IN HEBEI PROVINCE

\begin{tabular}{|c|c|c|c|c|c|}
\hline \multicolumn{6}{|c|}{ Output } \\
\hline \multicolumn{2}{|c|}{ DMU } & \multirow{3}{*}{$\begin{array}{c}\text { Carbon } \\
\text { emissions } \\
\text { (Ten } \\
\begin{array}{c}\text { thousand } \\
\text { tons ) }\end{array} \\
4760.88\end{array}$} & \multirow{3}{*}{$\begin{array}{c}\begin{array}{c}\text { Populati } \\
\text { on (Ten } \\
\text { thousand } \\
\text { ) }\end{array} \\
1075.19\end{array}$} & \multirow{3}{*}{$\begin{array}{c}\begin{array}{c}\text { GDP } \\
\text { (One } \\
\text { hundred } \\
\text { million } \\
\text { yuan) }\end{array} \\
7423.06\end{array}$} & \multirow{3}{*}{$\begin{array}{c}\begin{array}{c}\text { Energy } \\
\text { Consumpti } \\
\text { on (Ten } \\
\text { thousand } \\
\text { tons } \\
\text { standard } \\
\text { coal) }\end{array} \\
6121.09\end{array}$} \\
\hline DMU1 & & & & & \\
\hline (SJZ) & figure & & & & \\
\hline & $\begin{array}{l}\text { Improved } \\
\text { figure }\end{array}$ & 4339.54 & 1375.59 & 7423.06 & 6121.09 \\
\hline \multirow[t]{2}{*}{$\begin{array}{l}\text { DMU2 } \\
\text { (CD) }\end{array}$} & $\begin{array}{l}\text { Current } \\
\text { figure }\end{array}$ & 1446.55 & 357.08 & 2395.93 & 1500.83 \\
\hline & $\begin{array}{l}\text { Improved } \\
\text { figure }\end{array}$ & 1158.83 & 398.08 & 2395.93 & 1500.83 \\
\hline \multirow[t]{2}{*}{$\begin{array}{c}\text { DMU3 } \\
\text { (ZJK) }\end{array}$} & $\begin{array}{l}\text { Current } \\
\text { figure }\end{array}$ & 1516.93 & 450.78 & 2139.82 & 1835.56 \\
\hline & $\begin{array}{c}\text { Improved } \\
\text { figure }\end{array}$ & 1304.26 & 450.78 & 2139.82 & 1835.56 \\
\hline \multirow[t]{2}{*}{$\begin{array}{l}\text { DMU5 } \\
\text { (TS) }\end{array}$} & $\begin{array}{l}\text { Current } \\
\text { figure }\end{array}$ & 9982.99 & 788.25 & 10635.82 & 12395.06 \\
\hline & $\begin{array}{l}\text { Improved } \\
\text { figure }\end{array}$ & 8063.26 & 2321.25 & 10635.82 & 12395.06 \\
\hline \multirow[t]{2}{*}{$\begin{array}{c}\text { DMU6 } \\
\text { (LF) }\end{array}$} & $\begin{array}{l}\text { Current } \\
\text { figure }\end{array}$ & 4839.44 & 464.88 & 3091.04 & 6132.19 \\
\hline & $\begin{array}{l}\text { Improved } \\
\text { figure }\end{array}$ & 3631.52 & 919.18 & 3091.04 & 6132.19 \\
\hline \multirow[t]{2}{*}{$\begin{array}{c}\text { DMU8 } \\
(\mathrm{CZ})\end{array}$} & $\begin{array}{l}\text { Current } \\
\text { figure }\end{array}$ & 6937.86 & 744.64 & 4705.29 & 9638.91 \\
\hline & $\begin{array}{l}\text { Improved } \\
\text { figure }\end{array}$ & 5683.49 & 1428.54 & 4705.29 & 9638.91 \\
\hline \multirow[t]{2}{*}{$\begin{array}{l}\text { DMU11 } \\
\text { (HD) }\end{array}$} & $\begin{array}{l}\text { Current } \\
\text { figure }\end{array}$ & 4077.53 & 964.68 & 5213.59 & 4913.74 \\
\hline & $\begin{array}{l}\text { Improved } \\
\text { figure }\end{array}$ & 3360.70 & 1025.48 & 5213.59 & 4913.74 \\
\hline
\end{tabular}

TABLE IV shows,Shijiazhuang's DEA is invalid, in order to achieve DEA effective, we should reduce inputs, that should reduce carbon emissions 4,213,400 tons, increase the volume of output, that population increased 3.004 million; Chengde's DEA is invalid, in order to achieve DEA effective, we should reduce inputs, that should reduce carbon emissions 2,877,200 tons, increase the volume of output, that population increased 0.41 million; Zhangjiakou's DEA is invalid, in order to achieve DEA effective, we should reduce inputs, that should reduce carbon emissions 2,126,700 tons; Tangshan's DEA is invalid, in order to achieve DEA effective ,we should reduce inputs, that should reduce carbon emissions 19,197,300 tons, increase the volume of output, that population increased 15.33 million; Langfang's DEA is invalid, in order to achieve DEA effective, we should reduce inputs, that should reduce carbon emissions $10,279,200$ tons, increase the volume of output, that population increased 4.543 million; Cangzhou's DEA is invalid, in order to achieve DEA effective, we should reduce inputs, that should reduce carbon emissions $12,543,700$ tons, increase the volume of output, that population increased 6.893 million; Handan's DEA is invalid, in order to achieve DEA effective, we should reduce inputs, that should reduce carbon emissions 7,168,300 tons, increase the volume of output, that population increased 0.608 million.

In order to achieve the national carbon emissions intensity decreased by $17 \%$ target in 2015 than in 2010, Hebei Province should reach the national average target at least, that in 2015 
the province's carbon intensity decreased by $17 \%$ compared to 2010. According to estimates, in 2010, Hebei Province's carbon intensity is $1.0867 \mathrm{t} /$ ten thousand yuan, without the implementation of low-carbon development strategies, according to the current model of economic development and speed, according to the forecast, the province's carbon intensity $0.9150 \mathrm{t} /$ ten thousand yuan in 2015 , although carbon intensity showed a decline compared to 2010 , a decrease of $15.8 \%$, did not meet the target that the province's 2015 carbon intensity of $17 \%$ decline compared to 2010 . According to DEA evaluation results, after improving the cities whose DEA is weaker effective or ineffective, make the cities' DEA is effective, then according to the results of calculations ,after the improvement, the province's carbon intensity may be $0.783 \mathrm{t} /$ ten thousand yuan in 2015 , decreased by $27.9 \%$ compared to 2010 , fully able to achieve carbon emission reduction target of $17 \%$.

\section{CONCLUSION AND OUTLOOK}

Now Hebei province is undergoing a rapid period of urbanization and industrialization. With the rapid economic development and the continuous improvement of living standards, the requirement for energy grows more and more rapidly.Coal is the main energy in china's energy structure,it causes massive release of greenhouse gases,such as carbondioxides.How Hebei province both to achieve sustained economic growth,but also to effectively reach their emission reduction targets.For this, the aim of overall carbon reduction targets of "2015 national carbon emissions intensity by $17 \%$ compared to 2010 ". Clearing the carbon emission reduction responsibility in Hebei Province.First of all,predicting the input and output variables of DEA model.Then the paper uses DEA model to progress the efficiency analysis and economic evaluation for 11 prefecture-level city in Hebei carbon emissions in 2015.It obtains carbon emission allocating options of DEA efficiency and some suggestions are put forward.The results show that to achieve economic development in the reduction process is entirely possible.It provides a reference for the development of a low carbon economy over the level city in Hebei province.

\section{SHORTCOMINGS}

A. The distribution of carbon reduction responsibilities,After the development of a low carbon economy over the level city in Hebei province to provide a reference.The total amount of carbon emission reduction target has a fixed feature.So this paper can only get the initial calculation of the responsibility of the regional distribution of carbon emissions relative efficiency.The results can not be achieved by adjusting the allocation of areas to enhance the efficiency of the DEA.

B. Determining the distribution plan must consider both the principles of fairness and efficiency.Allocation scheme can only meet DEA effective and And does not reflect the fairness of allocation in this paper.

For these shortcomings it still need to conduct in-depth and meticulous research.

\section{ACKNOWLEDGMENT}

Funding of the Energy Economic Development Strategy Research Base Project at Hebei Soft Science Research Base.

\section{REFERENCES}

[1] Tan Lin, Junfei Ning. Study on the Allocate Efficiency of EU National Carbon Emissions Based on Zero and DEA Model. ECONOMICS Technology 2011. 28(3): 36-50.

[2] Liqun Zheng. Sharing the Carbon Emission Reduction Responsibility across Chinese Provinces: A Zero Sum Gains DEA Model. Resource Science 2012. 34(11): 2087-2096.

[3] Zhen Wang, Dingtao Zhao. Study on Carbon Reduction Shared Responsibility among Regional under Open Economy. SCIENCE OF SCIENCE AND MANAGEMENT OF S. \& T 2012, 33(07): 33.

[4] Yingzhi Xu,Yun Zhang. Study on Chinese Regional Carbon Reduction Responsibility and Potential of Carbon Reduction. Finance and Trade Research 2013, 24(2).

[5] Shoukang Qin. Comprehensive Evaluation Principles and Applications. Beijing: Electronic Industry Press 2001.

[6] Qunling Wei. Data Envelopment Analysis. Beijing: Science Press 2004.

[7] Tan Lin,Junfei Ning. Study on Allocate Efficiency of European Countries Carbon Emissions Based on A Zero Sum Gains DEA Model. ECONOMICS Technology 2011,28(3) : 36-50.

[8] Jing Wu,Xiaozhe Ma,Zheng Wang. Study on Chinese Provinces Carbon Emissions Quotas. Fourth study 2010,30(3) : 481-488.

[9] Xiuping Zou,Shaofeng Chen,Miao Ning.etc. An Empirical Analysis of Carbon Emission Factors of Chinese Provincial Area. Ecological and economic 2009,(03) : 34-37. 